\title{
Editorial
}

\section{Publisher's Note: Continued Publication of Clinics and Practice by MDPI}

\author{
Shu-Kun Lin ${ }^{1}$, Unai Vicario ${ }^{2}$ and Franck Vazquez ${ }^{1, * \mathbb{C}}$ \\ 1 MDPI, St. Alban-Anlage 66, CH-4052 Basel, Switzerland; lin@mdpi.com \\ 2 MDPI, Avenida Madrid, 95, 08028 Barcelona, Spain; vicario@mdpi.com \\ * Correspondence: vazquez@mdpi.com
}

Received: 1 December 2020; Accepted: 1 December 2020; Published: 4 December 2020

Clinics and Practice was launched in 2011 and it has been published over the past nine years by PAGEPress Publications [1]. Dr. Camillo Porta has served as its Editor-in-Chief since its inception [2].

We are delighted to take over the publication of Clinics and Practice from PAGEPress and wish to ensure the reader that we will continue to serve health professionals and clinicians well. Clinics and Practice complements the MDPI portfolio of medical journals very well [3,4], especially Journal of Clinical Medicine [5], Medicina [6], and Medical Sciences [7], and strengthens the trans-disciplinary bridge between basic sciences and applied sciences across MDPI journals.

We will regularly publish four quarterly issues from 2021.

We hope that you enjoy publishing your work in Clinics and Practice [8]!

\section{References}

1. Homepage at PAGEPress. Available online: https://www.clinicsandpractice.org/index.php/cp (accessed on 30 November 2020).

2. Istituti Clinici Scientifici Maugeri. Available online: https://www.icsmaugeri.it/professionisti/camillo-porta (accessed on 2 December 2020).

3. MDPI Medicine \& Pharmacology Journals. Available online: https://www.mdpi.com/subject/med-pharma (accessed on 30 November 2020).

4. MDPI Public Health \& Healthcare Journals. Available online: https://www.mdpi.com/subject/health (accessed on 30 November 2020).

5. Journal of Clinical Medicine Homepage. Available online: https://www.mdpi.com/journal/jcm (accessed on 30 November 2020).

6. Medicina Homepage. Available online: https://www.mdpi.com/journal/medicina (accessed on 30 November 2020).

7. Medical Sciences Homepage. Available online: https://www.mdpi.com/journal/medsci (accessed on 30 November 2020).

8. Clinics and Practice Homepage at MDPI. Available online: https://www.mdpi.com/journal/clinpract (accessed on 2 December 2020).

Publisher's Note: MDPI stays neutral with regard to jurisdictional claims in published maps and institutional affiliations.

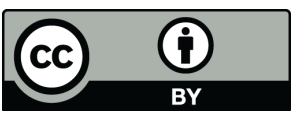

(C) 2020 by the authors. Licensee MDPI, Basel, Switzerland. This article is an open access article distributed under the terms and conditions of the Creative Commons Attribution (CC BY) license (http://creativecommons.org/licenses/by/4.0/). 